\title{
Sistem Informasi Pengelolaan Laboratorium Komputer UPI-YPTK Padang
}

\author{
Wahyu Joni Kurniawan \\ Dosen Teknologi Informatika STMIK Amik RIAU \\ Wahyu.j.kurniawan@gmail.com
}

\begin{abstract}
ABSTRAK
Dengan banyaknya peralatan yang ada pada laboratorium, maka dibutuhkan suatu pengelolaan yang dapat memberikan informasi peralatan yang ada dan yang dibutuhkan di setiap labor. Pengelolaan ini berguna untuk menampilkan data peralatan yang ada. Dan juga memberikan informasi jadwal kuliah disetiap labor sehingga memudahkan asisten mengetahui dosen yang akan mengajar di masin-masing labor. Dengan adanya pengelolaan ini, maka dapat diketahui data lengkap peralatan pada laboratorium dan jumlah komputer yang dapat digunakan. Dan inipun mempermudah Asisten Labor memberikan data kebutuhan untuk labor tersebut.Berdasarkan hasil penelitian pada Laboratorium Komputer UPI YPTK, sistem ini dapat mengoptimalkan informasi dari asistem kepada puskom maupun sebaliknya. Dengan adanya perancangan sistem informasi ini dapat memudahkan asisten dalam melakukan permintaan inventaris labor. Sistem informasi ini memberikan kemudahan bagi dosen yang akan mengadakan kuliah pengganti, karena dapat mengakses langsung dari labor tanpa harus pergi ke puskom terlebih dahulu. Dengan sistem yang sudah ada, masih ada ditemukan kekurangan dalam hal pengelolaan laboratorium, baik itu dalam kehadiran asisten, barang kebutuhan labor, dan juga jadwal kuliah yang sudah ditetapkan.
\end{abstract}

Kata kunci: Penulis dapat menyertakan maksimum enam kata kunci.

\section{PENDAHULUAN}

Informasi merupakan hasil pengolahan data yang disajikan sedemikian rupa agar dapat memberikan persepsi tertentu kepada para pembacanya. Oleh karena sangat besarnya ketergantungan manusia terhadap informasi, maka kualitas informasi harus selalu ditingkatkan. Beberapa faktor penentu kualitas informasi adalah keakuratan, relevansi dan kemudahan untuk memperolehnya. Untuk memenuhi beberapa faktor tersebut, maka tidak cukup kalau pengelola data hanya mengandalkan kemampuan fisik ditambah dengan peralatan bantu sekedarnya, melainkan dibutuhkan alat bantu berkecepatan tinggi dan sangat akurat dalam memproses data tersebut.

Komputer merupakan alat bantu pengolahan data yang dapat dihandalkan tidak hanya kecepatannya, melainkan juga keakuratan dan daya tahannya untuk melakukan pemrosesan data dalam jumlah besar. Saat ini komputer telah dijadikan teknologi pokok dalam pengolahan data dan penyajian informasinya. Berbagai Perusahaan baik yang bergerak dalam sektor retail maupun jasa, telah memanfaatkan teknologi komputer untuk menghasilkan informasi yang akan digunakan sebagai dasar dalam pengambilan keputusan penting.

\section{LANDASAN TEORI}

\subsection{Konsep Dasar Sistem Komputerisasi}

Tujuan komputer diciptakan adalah sebagai alat pengolah data untuk menghasilkan informasi-informasi yang dibutuhkan. Untuk tercapainya tujuan tersebut, komputer harus didukung oleh elemen-elemen berikut ini, yaitu :

a. Software (perangkat lunak/piranti lunak) ialah : Program yang berisi perintahperintah untuk melakukan pengolahan data. 


\section{Jurnal Edik Informatika}

ISSN : 2407-0491

E-ISSN : 2541-3716

Penelitian Bidang Komputer Sains dan Pendidikan Informatika

V2.i1(95-101)

b. Hardware (perangkat keras/piranti keras) ialah : Peralatan pada sistem komputer yang secara fisik terlihat dan dapat dijamah.

c. Brainware yaitu : Manusia yang terlibat dalam mengoperasikan sistem komputer.

Ketiga elemen tersebut saling berhubungan dan membentuk satu kesatuan. Kemudian dari hasil interaksi antara tiga elemen tadi maka sistem komputer akan dapat berjalan sebagaimana mestinya.

\subsubsection{Konsep Dasar Sistem}

Menurut Jogiyanto. HM, (2008:34) mendefinisikan "Sistem dapat didefinisikan dengan pendekatan prosedur dan pendekatan komponen".

Didalam sistem ada dua macam pendekatan:

1. Berdasarkan Pendekatan Prosedur

Sistem adalah suatu jaringan kerja dari prosedur-prosedur yang saling berhubungan, berkumpul bersama-sama untuk melakukan suatu kegiat-an atau untuk menyelesaikan suatu sasaran yang tertentu.

2. Berdasarkan Penekanan Komponen

Sistem adalah kumpulan dari elemenelemen yang berinteraksi untuk mencapai suatu tujuan tertentu.

\subsubsection{Konsep Dasar Sistem}

Komponen-komponen dalam sebuah sistem tidak dapat berdiri sendiri, saling berhubungan dan berinteraksi dalam membentuk suatu kesatuan sehingga sasaran atau tujuan sistem tercapai.

Sistem mempunyai karakteristik atau sifatsifat yang tertentu, yaitu :

1. Komponen Sistem.

2. Batas Sistem (Boundary).

3. Lingkaran Luar Sistem (Environment).

4. Penghubung Sistem (Interface).

5. Masukan Sistem (Input).

6. Keluaran Sistem (Output).

7. Pengolahan Sistem.

8. Sasaran.

\subsubsection{Pengertian Informasi}

mendefinisikan "Informasi adalah data yang diolah menjadi bentuk yang berguna bagi para pemakainya."

Untuk dapat berguna, maka informasi harus didukung oleh tiga pilar :

1. Tepat Kepada Orangnya atau Relevan (Relevance).

2. Tepat Waktu (Timelines).

3. Tepat Nilainya (Accurate).

\subsubsection{Pengertian Sistem Informasi}

Sistem informasi adalah suatu sistem didalam suatu organisasi yang mempertemukan kebutuhan pengolahan transaksi harian, medukung operasi, bersifat manajerial dan kegiatan strategi dari suatu organisasi dan menyediakan pihak luar tertentu dengan laporanlaporan yang diperlukan.

\subsection{Daur Hidup Pengembangan Sistem (System Development Life Circle)}

Daur hidup sistem merupakan suatu metode yang digunakan dalam pengembangan sistem yang terdiri dari beberapa tahapan, ditandai oleh pendekatan analisa sistem dan disain sistem. Pengembangan sistem ini dibedakan menurut jenis sistem informasi yang akan dikembangkan yaitu:
1. Sistem Pemrosesan Transaksi (Transaction Prosessing System)
2. Sistem Informasi Manajemen (Information Management System).
3. Sistem Pengambilan Keputusan (Decision Support System)
4. Sistem Ahli (Expert Sistem)

\subsubsection{Alat Bantu Dalam Perancangan Sistem}

Untuk dapat melakukan langkah-langkah pengembangan sistem sesuai dengan metodologi pengembangan sistem yang terstruktur maka dibutuhkan alat dan teknik untuk melaksanakannya. Alat-alat yang digunakan dalam suatu perancangan sistem umumnya berupa suatu gambaran atau diagram.

Adapun alat bantu yang digunakan dalam perancangan atau pengembangan sistem pada penelitian adalah :

\subsubsection{Aliran Sistem Informasi (ASI)}




\section{Jurnal Edik Informatika}

ISSN : 2407-0491

E-ISSN : 2541-3716

Penelitian Bidang Komputer Sains dan Pendidikan Informatika

V2.i1(95-101)

Aliran sistem informasi merupakan bagan alir yang menunjukan arus dari program dan formulir termasuk tembusan-tembusannya. Aliran sistem informasi mempunyai simbol-simbol.

\subsubsection{Data Flow Diagram (DFD)}

DFD menggambarkan sistem yang sedang berjalan dan diusulkan secara logika tanpa mempertimbangkan lingkungan fisik data.

\subsubsection{Contex Diagram}

Context diagram adalah gambaran umum tentang suatu sistem yang terdapat dalam suatu organisasi yang memperlihatkan batasan sistem, adanya interaksi antara eksternal entity dengan suatu sistem dan informasi secara umum mengalir di antara entity dan sistem. Context diagram ini merupakan alat bantu yang digunakan dalam menganalisa sistem yang akan dikembangkan.

\subsubsection{Entity Relationship Diagram (ERD)}

Entity Relationship Diagram adalah diagram yang menggambarkan hubungan antara file-file yang ada dalam database.

\subsubsection{Program Flowchart}

Program Flowchart adalah gambaran dalam bentuk diagram alir dari algoritma-algoritma dalam suatu program, yang menyatakan arah alur program tersebut.

\subsection{Konsep Dasar Bahasa Pemrograman PHP dan HTML}

PHP adalah singkatan dari Personal Home Page yang merupakan bahasa standar yang digunakan dalam dunia website. PHP adalah bahasa pemrograman yang berbentuk script yang diletakkan didalam web server. Ada beberapa pengertian tentang PHP, akan tetapi PHP dapat diartikan sebagai Hypertext Preeprocessor. Ini merupakan bahasa yang hanya dapat berjalan pada server yang hasilnya dapat ditampilkan pada klien. Interpreter PHP dalam mengeksekusi kode PHP pada sisi server disebut serverside, berbeda dengan mesin maya Java yang mengeksekusi program pada sisi klien (client-server).

Hypertext Markup Language merupakan kepanjangan dari kata HTML. HTML adalah script dimana kita bisa menampilkan informasi dan daya kreasi kita lewat intenet. HTML juga merupakan file teks murni yang dapat dibuat dengan editor teks sembarang yaitu yang dikenal sebagai web page atau dokumen yang disajikan dalam web browser. Dokumen ini umumnya berisi informasi atau interface aplikasi didalam internet.

\subsection{Konsep Dasar Database}

Dtabase adalah kumpulan file-file atau tabel-tabel yang saling berelasi. Adapun pendapat beberapa ahli mengenai database, yaitu: Andi Sunyoto (2007:123) menyatakan bahwa database adalah kumpulan file-file atau tabel-tabel yang saling berelasi atau berhubungan antara satu dengan yang lain. Kusrini (2007:2) menyatakan bahwa database adalah kumpulan data yang saling berelasi. Suatu database terbentuk dengan memiliki hirarki, seperti yang terlihat pada gambar 2.1.

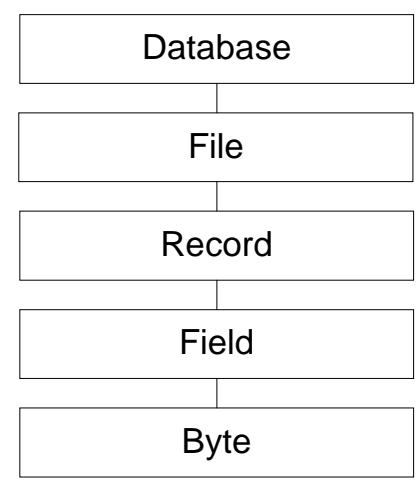

Gambar 2.1 Tingkatan Database

\subsubsection{Model Database}

Pada dasarnya kekuatan dan kelemahan dari model ini mencerminkan perbedaan filosofi manajemen database. Berapa kriteria dalam mengevaluasi model data yaitu:

1. Sederhana (Simplycity). Sebuah kesederhanaan sedikit mungkin jumlah tiga struktur, kaidah dan atribut.

2. Pemodelan yang mendekati kenyataan (modelling direction).

\section{Diterbitkan Oleh Program Studi Pendidikan Informatika STKIP PGRI Sumbar}


3. Sebuah model sebaiknya mendekati konsep yang nyata di dunia.

4. Kemampuan menyimpan gambar (picturebility).

5. Teknologi tidak bertentangan. Sebuah model seharusnya menggunakan terminologi yang tidak bertentangan dengan terminology yang lainnya. yaitu:

Metode-metode yang digunakan ada tiga ,

1. Model relation

Relasi adalah hubungan antara tabel yang satu dengan yang lainnya. lain:

Adapun ada beberapa bentuk relasi antara

a. Relasi One To One (Satu ke satu)

Ketika satu record pada satu tabel hanya berhubungan dengan satu record pada satu tabel lainnya.

b. Relasi One To Many (Satu ke Banyak ) Ketika satu record pada satu tabel dengan banyak record pada tabel lainnya.

c. Relasi Many To Many

Ketika banyak record pada suatu tabel berhubungan pada banyak record pada tabel lainnya.

2. Model hirarki

Seiring dikenal dengan Binary tree (pohon biner atau binary relationship), merupakan jenis struktur tree yang terbaik dimana data akar (root) mempunyai beberapa cabang.

\subsubsection{Langkah -Langkah Perancangan Database}

Dalam perancangan database perlu diperhatikan langkah-langkah sebagai berikut:

a. Menentukan kebutuhan input dari suatu baru.

Input yang akan dirancang dapat ditentukan dari data flow diagram (DFD) sistem baru yang telah dibuat.

b. Menetukan parameter data input

Setelah input-input yang akan dirancang telah dapat ditentukan maka parameter dari input selanjutnya juga dapat ditentukan. Parameter ini meliputi:

1. Bentuk dari input dan dokumen dasar

2. Sumber input

3. Volume input

4. Periode input.

\subsubsection{Pengertian MySQL}

$S Q L$ adalah sebuah konsep pengoperasian database, terutama untuk pemilihan atau seleksi dan pemasukan data, yang memungkinkan pengoperasian data dikerjakan dengan mudah secara otomatis. Keandalan suatu sistem database (DBMS) dapat diketahui dari cara kerja optimizernya dalam melakukan proses perintah $S Q L$, yang dibuat oleh user maupun programprogram aplikasinya. Sebagai database server, $M y S Q L$ dapat dikatakan lebih unggul dibandingkan database server lainnya dalam query data. Hal ini terbukti untuk query yang dilakukan oleh single user, kecepatan query $M y S Q L$ bisa sepuluh kali lebih cepat dari PostgreSQL dan lima kali lebih cepat dibandingkan Interbase.

\section{ANLISA DAN HASIL \\ 3.1 Analisa Sistem yang Sedang Berjalan 3.1.1 Aliran Sistem Informasi Lama}

Aliran sistem informasi pemberian daftar jadwal kuliah dan jadwal pengganti adalah sebagai berikut :

1. Pihak Puskom membuat rekap laporan kuliah tetap, satu untuk arsip dan satu lagi diberikan kepada setiap labor.

2. Dosen yang akan mengadakan kuliah penggantiakan memberikan laporan kuliah pengganti pada pihak puskom dan pihak Puskom akan memeriksa tanggal dan jam berapa jadwal kosong.

3. Setelah melakukan pemeriksaan, Pihak puskom merekap laporan yang satu untuk arsip dan satu lagi diberikan pada asisten labor bersangkutan.

Aliran sistem informasi pemberian daftar jadwal kuliah tetap dan pengganti tersebut dapat dilihat pada gambar 3.1.

Selanjutnya aliran sistem informasi kebutuhan inventaris labor, adalah sebagai berikut :

1. Asisten memberikan laporan kebutuhan inventaris pada pihak puskom. Puskom memeriksa laporan dan merekap laporan yang ada dan yang satu menjadi arsip dan satu lagi diberikan pada pihak yayasan. 


\section{Jurnal Edik Informatika}

ISSN : 2407-0491

E-ISSN : 2541-3716

Penelitian Bidang Komputer Sains dan Pendidikan Informatika

V2.i1(95-101)

2. Yayasan melakukan pembelian terhadap barang yang dibutuhkan setiap labor sesuai dengan laporan kebutuhan yang ada.

3. Setelah melakukan pembelian, yayasan merekap faktur pembelian yang mana satu untuk arsip dan satu lagi untuk diberikan pada pihak puskom beserta barang kebutuhan inventaris

Untuk memperjelas aliran sistem informasi pemberian daftar nilai tersebut dapat dilihat pada gambar 3.2.

\subsubsection{Kelemahan Sistem yang Sedang Berjalan}

Dari hasil pengamatan dan penelitian yang telah, maka dapat didefinisikan beberapa kelemahan dan kekurangan, sebagai berikut:

1. Membutuhkan waktu yang lama dalam pengolahan data karena dilakukan secara manual

2. Pada proses ini masih menggunakan berkas yang banyak dalam melakukan proses pengolahannya.

Dari kendala-kendala tersebut di atas maka diajukan usulan sistem baru yang diharapkan dapat mengatasi kendala-kendala yang ada dengan melakukan pengolahan data secara komputerisasi.

\subsection{Disain Sistem Baru \\ 3.2.1 Disain Global}

Tujuan dari disain global adalah memberikan gambaran secara umum kepada user tentang sistem yang baru. Rancangan sistem mengidentifikasikan komponen-komponen sistem informasi yang akan didisain secara rinci. Disain sistem secara global ini sangat berguna bagi penulis dalam melakukan peranacangan yang lebih rinci.

\subsubsection{Analisa Kinerja Sistem Baru}

Untuk memperjelas Aliran Sistem Informasi daftar kebutuhan inventaris labor dan jadwal kuliah pengganti, dapat dilihat pada gambar 3.3.

\subsubsection{Context Diagram}

Context diagram adalah gambaran sistem secara logikal, gambaran ini tidak bergantung pada perangkat keras, perangkat lunak maupun organisasi file. Keuntungan dari context diagram adalah memudahkan pemakai untuk mengerti sistem yang akan dikembangkan.

\subsubsection{Data Flow Diagram Level 0}

Data flow diagram merupakan gambaran aliran data dari sistem dibangun dengan menghubungkan proses-proses yang terjadi, yang didapatkan berdasarkan hasil dari context diagram yang telah dibuat.

\subsubsection{Entity Relationship Diagram (ERD)}

Entity Relatioship Diagram adalah suatu model jaringan kerja (Network) yang menguraikan susunan data yang distore dari sistem secara abstrak. Entity Relationship Diagram menunjukan hubungan antar entity didalam sistem, entity adalah suatu tempat, benda yang semuanya memiliki nama yang umum.

\subsubsection{Disain Struktur Program}

Berdasarkan hasil analisa dan disain sistem baru, maka dirancang sebuah program aplikasi untuk merealisasikan hasil disain sistem baru yang berbasiskan komputer.

Disain terinci merupakan kunci utama suksesnya suatu sistem yang akan dirancang, karena dalam perancangan secara terinci akan dimuat semua rancangan yang mengarah pada teknik pelaksanaannya, dan merupakan lanjutan dari perancangan sistem secara umum. Disain ini meliputi Disain output, Disain input, dan Disain file.

\subsubsection{Disain Output}

Disain output atau rancangan dimaksud untuk menetapkan format tampilan yang digunakan sebagai media untuk melihat hasil akhir dari sebuah website yang telah dibangun, sebagai bentuk data yang dapat dilihat pada layar komputer.

\subsubsection{Disain Input}


Disain Input ini, dapat menggunakan sebuah tool (alat bantu) yaitu merupakan halaman yang digunakan oleh administrator dan asisten untuk melakukan pengentrian dan pengeditan isi dari sebuah website.

\subsubsection{Disain File}

Setelah Disain input dan Disain output dibentuk, maka selanjutnya adalah merancang file. File merupakan kumpulan record-record yang sejenis, dari file tersebut data akan direkam dalam media penyimpanan dan rancangan file disusun berdasarkan input sebelumnya.

\section{Implementasi Sistem}

Tahap implementasi sistem merupakan salah satu tahap dalam daur hidup pengembangan sistem, dimana tahap ini merupakan tahap meletakkan sistem informasi supaya siap untuk dipakai. Dalam tahap ini, berlangsung beberapa aktifitas secara berurutan yakni mulai dari menerapkan rencana implementasi, melakukan kegiatan implementasi, dan tindak lanjut implementasi.

Supaya implementasi berjalan dengan baik dan sesuai dengan yang diharapkan, maka suatu rencana implementasi perlu dibuat terlebih dahulu. Rencana implementasi ini dimaksudkan untuk mengatur biaya serta waktu yang dibutuhkan selama tahap implementasi.

Pemilihan brainware atau personil menjadi langkah pertama dalam kegiatan implementasi yang dilakukan setelah perencanaan diputuskan. Personil inilah yang akan menjalankan sistem nantinya.

Kegiatan implementasi dilanjutkan dengan pemilihan tempat serta instalasi, baik itu perangkat keras maupun perangkat lunak dari sebuah sistem. Penempatan perangkat keras perlu ditentukan agar terjaga keamananya. Penempatan perangkat keras yang baik harus memenuhi beberapa kriteria, seperti suhu ruangan yang stabil, penerangan yang cukup, memiliki alat pendeteksi terhadap gangguan. Setelah penempatan perangkat keras ditentukan, maka instalasi perangkat lunak pun harus diperhatikan, yaitu software yang digunakan dalam sistem informasi pengelolaan laboratorium komputer UPI YPTK.

\section{Kesimpulan}

Berdasarkan hasil penelitian pada Laboratorium Komputer UPI YPTK, maka dapat diambil beberapa kesimpulan :

1. Dengan adanya sistem informasi ini dapat mengoptimalkan informasi dari asistem kepada puskom maupun sebaliknya.

2. Dengan adanya perancangan sistem informasi ini dapat memudahkan asisten dalam melakukan permintaan inventaris labor.

3. Sistem informasi ini memberikan kemudahan bagi dosen yang akan mengadakan kuliah pengganti, karena dapat mengakses langsung dari labor tanpa harus pergi ke puskom terlebih dahulu.

Dengan menggunakan sistem ini, pihak PUSKOM tidak perlu lagi menggunakan excell dalam membuat absensi asisten.

\section{DAFTAR PUSTAKA}

Jogiyanto H.M. 2001. Analisis dan Desain Sistem Informasi. Yogyakarta: Andi Offset.

Informasi. Yogyakarta : Andi Offset.

MADCOMS. 2004. Aplikasi PHP \& MySQL untuk Membuat Website Interaktif. Madiun : Andi Offset. 2008. PHP Dan MySQL untuk pemula. Madiun. Andi Offset. 2012. Aplikasi Pemrograman JavaScript untuk Halaman WEB. Madiun : Andi Offset

Kadir, Abdul. 2008. Belajar Database Menggunakan MySQL. Yogyakarta : Andi Offset.

2009. Membuat Aplikasi Web dengan PHP dan Database MySQL. Yogyakarta : Andi offset. 2011. From Zero To A Pro Membuat Aplikasi Laporan MenggunakanPHP. Yogyakarta. Andi Publisher.

Hakim, Lukmanul. 2008. Membongkar Rahasia PHP. Yogyakarta : Lokomedia. 2010. Bikin Website Super Keren dengan PHP dan JQUERY. Yogyakarta : Lokomedia. 
ISSN : 2407-0491

Jurnal Edik Informatika

E-ISSN : 2541-3716

Penelitian Bidang Komputer Sains dan Pendidikan Informatika

V2.i1(95-101)

Kasman, Akhmad Dharma. 2012. Membuat

Sendiri Website Pertemanan dengan

PHP dan JQUERY. Yogyakarta :

Lokomedia. 